\title{
Architectural Heritage: A Discussion on Conservation and Safety
}

\author{
Antonio Borri and Marco Corradi *(iD) \\ Department of Engineering, University of Perugia, 06125 Perugia, Italy; antonio.borri@unipg.it \\ * Correspondence: marco.corradi@unipg.it; Tel.: +39-(0)744-492-2908
}

Received: 20 January 2019; Accepted: 11 February 2019; Published: 13 February 2019

\begin{abstract}
This paper presents a study carried out in the Italian region of Umbria, after the 2016 Central Italy earthquake. The aim is to address the problem of the conservation and protection of architectural heritage in Italy. The application of retrofitting strategies, while improving the seismic performance of historic — and frequently listed by conservation bodies-buildings, will not significantly alter their appearance, will be reversible, and fall within the principle of minimum intervention (minimal (least) intervention (or conservative repair)). These issues were evaluated in the paper by considering the different points of view of structural engineers and conservators. Heavy structural-oriented interventions as well as the underestimation of the importance of the structural safety for masonry monuments has produced, in the past, irreversible damage to important buildings and monuments, and loss of architectural heritage in Italy. The requirement of structural safety, especially for monuments located in seismic-prone areas, is compared with the need for conservation. The Italian building guidelines for interventions of cultural heritage are also discussed, highlighting some limitations and important advancements.
\end{abstract}

Keywords: earthquake engineering; masonry structures; conservation; structural safety

\section{Introduction}

A renewed focus on safety issues in many areas of life has recently led to the creation of new regulations and standards, which have been inspired by the prevention of fatalities. New stringent Codes have been published in many parts of Europe on fire safety rules, security on building sites, and general safety conditions at workplaces. In many cases, this was after major disasters. A similar situation occurs when dealing with the building stock. In Italy, new territory areas have been progressively included into the requirement of seismic design. Nowadays, most new constructions in masonry, steel, timber, and reinforced concrete (RC) have to be designed according to the new, stringent seismic code. The situation concerning pre-existing building stock is more complex.

Italy has a very important architectural heritage and a long history. Italy is also a seismically active area, and the effects of earthquakes on monuments, buildings and assets are critically destructive, given the weak mechanical behavior of masonry when struck by seismic loads [1-4]. Unfortunately, only when such seismic events occur do institutions and general public become aware of the serious vulnerability of the national architectural heritage.

Serious damage and irreparable ruin of important unreinforced masonry (URM) buildings were recently recorded [5-12]. This happened in conjunction with fatalities and loss of historic memories and evidence. Destructive earthquakes struck central Italy in 1997 (Umbria-Marche), 2009 (L'Aquila), 2012 (Emilia), and 2016 (Central Italy) [13-15]. These events should further stress the need for a targeted prevention and protection of, at least, the most important architectural heritage monuments. However, the method used in the Italian guidelines for interventions on cultural heritage assets 
and monuments [16] is aimed at reducing and limiting structural works, giving higher priority to conservation issues and monitoring $[17,18]$.

In detail, the Italian Code $[19,20]$ and the Italian Guidelines [16] introduced the concept of Reduced Nominal Life (vita nominale ridotta in Italian, i.e., period of time during which the building can be considered as safe). However, contrary to what people believe, the recent destructive seismic events clearly demonstrated that such catastrophic events are more frequent than one thinks. Figure 1 shows an example of the irreparable damage to cultural heritage due to the missing implementation of effective and preventive interventions.

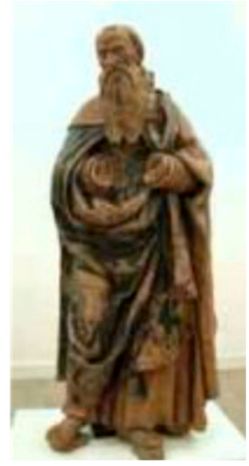

(a)

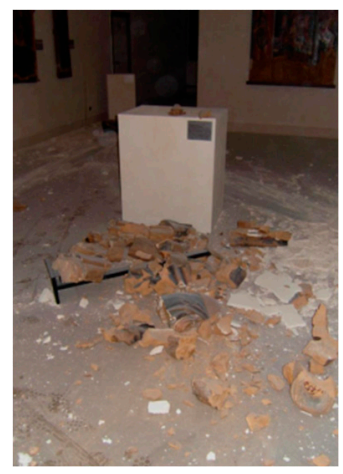

(b)

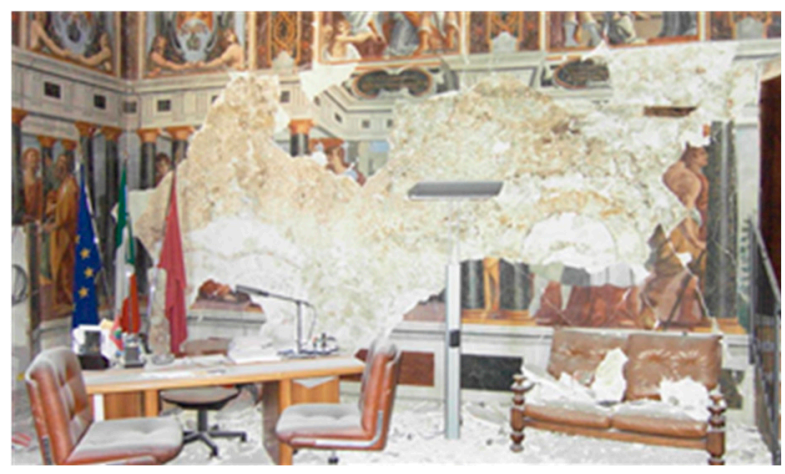

(c)

Figure 1. Irreparable damage to the cultural heritage due to the missing implementation of effective and preventive interventions: Example of the overturning and associated destruction of an antique statue in L'Aquila museum ((a) before the earthquake and (b) after); (c) serious damage/destruction of 16th-century frescos in Palazzo Branconio-Farinosi in L'Aquila after the 2009 Abruzzo earthquake.

Italy was struck by about thirty serious seismic events during the last three decades. All of these had a magnitude greater than 5. Important damage and loss of the architectural heritage was induced by the earthquake in Sicily (1990), Umbria-Marche (1997), Calabria (1998), Molise (2002), Abruzzo (2009), Emilia (2012), and Central Italy (2016). A return period of 10 years of a destructive earthquake in Italy seems to be an optimistic expectation.

A common approach is to consider all cultural heritage assets as equally important, and the consequence of this is a missing list of priorities of interventions. On the contrary, it should be considered that the seismic risk could be different from one to another building or heritage asset [21,22]. We believe that the correct approach to this problem should be based on an initial analysis of the most critical situations, in order to identify priorities of interventions on monuments and heritage artifacts. By doing this, governmental statutory bodies and local governments could implement more effective conservation and preservation policies, funding interventions where risk is greater. The common belief that risk is low is often induced by misleading observations: If a monument was constructed several hundred years ago, and it did not experience significant damage in the recent past, this does not imply that the risk is low: There is evidence of a large number of very old monuments having collapsed during the recent quakes.

Professor Giuffrè, one of the most experienced persons in the field of structural analysis of heritage structures, wrote in Reference [23]: “ . . properly-designed historic buildings, if subjected to a correct and continuous maintenance, experienced in their life severe seismic events and are still standing, demonstrating their ability to resist ..." . This entirely acceptable sentence clearly states the importance of a proper design and continuous maintenance. Testing from past earthquakes is clearly cited in the above statement, but structural safety can be achieved only when proper design, continuous maintenance, and testing are guaranteed.

Based on this, it should be concluded that when the design is not correct, or the used construction materials are subjected to degradation, or the so-called "rules of the art" in construction 
were not fulfilled, seismic events can make evident the structural vulnerabilities of heritage constructions [2,24-26].

Furthermore, it should be also noted that a lot of heritage masonry structures, although very ancient, never experienced a destructive earthquake in their life. The circumstance of their old age does not imply these structures can resist the dynamic action of an earthquake. For example, in L'Aquila, most of the heritage buildings that collapsed during the 2009 quake had been constructed (or reconstructed) after the 1703 quake. These buildings never experienced a destructive seismic event similar to the 2009 one. A similar situation occurred in 2012 in Emilia, and in 2016 in Umbria. In Emilia, most of the heritage buildings had been constructed after the 1570 earthquake. In L'Aquila, Emilia, and Umbria, several buildings, despite their age, were struck for the first time by a serious earthquake, and the lack or limited functionality of the wall-to-wall connections was the main cause of their collapse.

There is also another critical condition to consider, well-known by professor Giuffrè [23], in order to identify a "good historic building": The initial structural scheme of the building should not be altered by successive restorations and interventions. For those masonry structures, where modifications were made (i.e., removal of timber-beam floors and roofs, opening of new openings in the walls, addition of RC elements, etc.), testing from past earthquakes cannot be considered evidence of the ability to resist future seismic events. It is clear that these structurally-modified buildings never experienced a destructive earthquake.

Finally, degradation of construction materials and damage induced by past earthquakes is an issue, especially when this was not properly repaired or not repaired at all. These factors may cause significant reductions to the building's seismic capacity. Damage accumulation should always be considered. The principle of old construction = good construction is again challenged by the inevitable march of time.

This paper is a revised and expanded version of a paper entitled 'Structural Engineers vs. Conservators, Safety vs. Preservation: Problems, Doubts and Proposals' presented at the 1st International Conference TMM_CH Transdisciplinary Multispectral Modelling and Cooperation for the Preservation of Cultural Heritage, 10-13 October 2018, Athens, Greece [27].

\section{Dialogue between Structural Engineers and Conservators}

If we consider a generic historic building, with its common artistic assets (frescoes, statues, etc.), the design of an intervention aimed at improving the structural response of the building and its assets under a seismic motion requires a coordination between structural and service engineers, architects, conservators, and art historians. Furthermore, the supervision and control of the statutory conservation body, if the masonry structure is in its portfolio, has to be included during the decision process.

Clearly, the main objective is the preservation of the historic construction, and a constructive relationship between the different responsibilities is critical to this end. Beyond specific problems or particular cases, the success of this relationship highly depends on the condition that everyone, albeit with a different level of knowledge, is confident with the thematic areas of restoration and structural repair. Under this condition, a proper mutual understanding and evaluation of the different arguments will always be possible.

Unfortunately, the situation we face is complex with an extreme variety. We could find a reason by looking at the contents of university modules and academic pathways in general: Engineering students in Italy typically do not study restoration principles, conservation, and monitoring procedures. A similar situation occurs for students of the architectural faculties, where seismic issues and mechanics of masonry structures are rarely elaborated on. The consequence of this is a "cultural divide", which is not easy to overcome.

Furthermore, the competences of art historians and critics are needed when historic buildings contain artistic assets. While dialogue between engineers and architects has some common roots (the scientific background, the knowledge of statics and structural mechanics), with art historians, 
the situation is more challenging. Art historians play important roles in Conservation bodies in Italy and it is sometimes difficult, for a structural engineer, to report structural issues.

Undoubtedly, it is a cultural problem. The engineer's trust in numbers and physical-mathematical models, derives from their scientific background and it does not sit well with qualitative approaches. However, it should be remarked that responsibilities for the structural safety of a monuments lie almost entirely with structural engineers. Using common sense and good will, it is always possible to find appropriate solutions that are balanced between the need for a "conscious reinforcement" for structural engineers and a "conscious restoration" for conservators. That, unfortunately, has not always been the case in the past, and it is also sometimes not, today. At different points in time and depending on the positions of strengths of the actors, different extreme views alternately prevailed, producing unevenly distributed and dissimilar solutions on the Italian territory. These solutions were sometimes not worthy of support, resulting in disastrous results.

Following the Friuli 1976 and Irpinia 1980 earthquakes, the relationship between structural engineers and conservators varied significantly. After these quakes, invasive and inappropriate retrofitting interventions were carried out, justified by the need to comply with the new building code requirements. More recently, we faced opposite solutions, characterized by strong limitations to structural interventions or, less frequently, impositions of unilateral solutions, enforced by the conservation statutory bodies.

\section{Issues Produced by Building Codes}

The different approach of structural engineers and conservators is not the only problem we face. The Italian Building Codes, especially the ones in force in the 1980s and 1990s, suggested invasive retrofitting interventions, adding large quantities of new mass and thus increasing the seismic forces when the buildings were subjected to a seismic action.

This is the case of the frequent removal of light timber beam floors and their replacement with solid or hollow-core concrete. This was sadly required by the only need to use the POR calculation method [28] and the software based on this method, commonly employed by structural engineers and explicitly imposed by the Building Codes in terms of rigid horizontal diaphragms. These Codes also suggested the generalized use of RC ring-beams, to be applied at eave level or near the horizontal diaphragms of the floors. Dovetail RC joints were often added to increase the wall-to-wall level of connection. Evidence after recent earthquakes demonstrated the limited effectiveness of these interventions (Figure 2). Replacement of pre-existing timber-joist or timber-beam floors or roofs with new concrete-rib and hollow-block diaphragms was also common in the 1980s: This intervention highly increased the bending capacity of the floors, but the increment in mass and stiffness had deleterious effects on the seismic behavior of the building. The demolition of timber-beam floor causes vertical stresses to migrate to the external wall-leaf, and the subsequent reconstruction of the new concrete-rib and hollow-block floor produces high compressive stresses in the walls (Figure 3). However, this is typically limited to the indoor wall leaf. The consequence of this is the punching shear action of the floor and the overturning mechanism of the external wall leaf during an earthquake. 

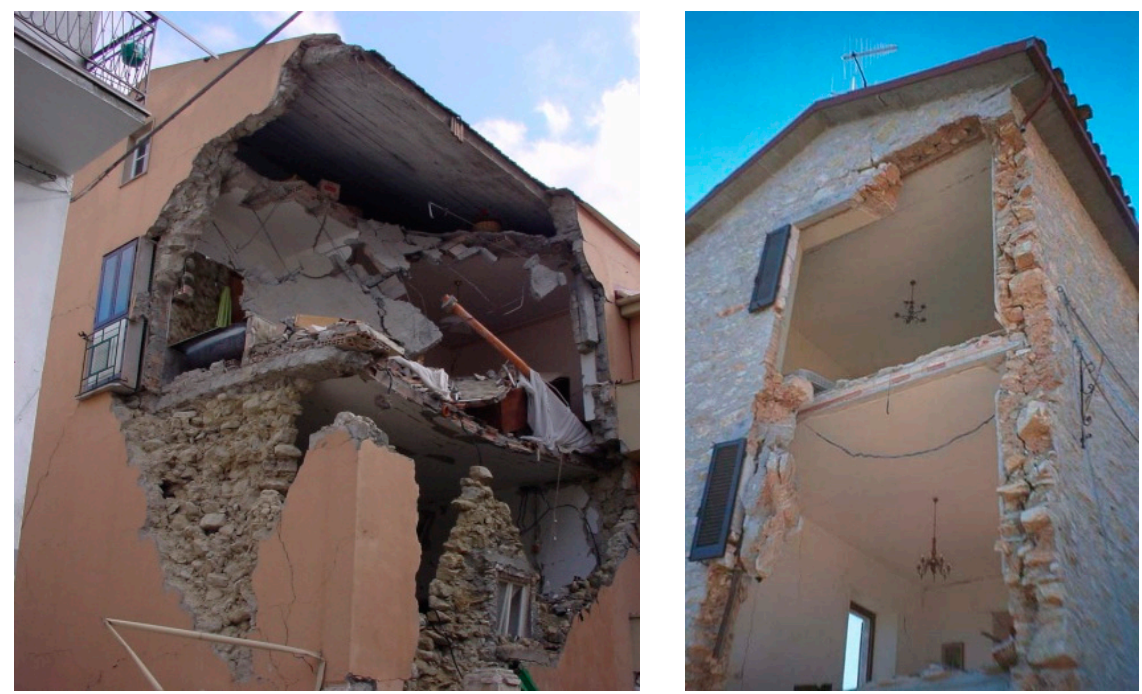

Figure 2. Examples of the effects of a typical intervention carried out in the 1980s in Italy: The intervention consisted of the removal of the timber-beam floor and roof, insertion of reinforced concrete (RC) ring beams, concrete-rib and hollow-block floor, RC slab roof.

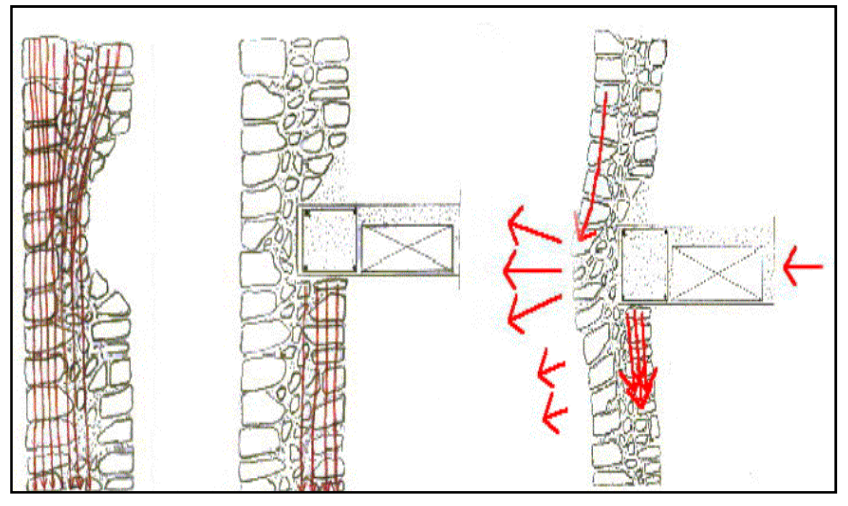

(a)

(b)

(c)

Figure 3. Typical effect of the demolition of a timber-beam floor and application of a new concrete-rib and hollow-block floor for a historic building made of double-leaf walls: The new floor typically rests only on one wall leaf, producing a redistribution of the vertical compressive stresses and thus facilitating the overturning mechanism of the external wall-leaf during an earthquake: (a) Stress redistribution, (b) high compressive stresses due to addition of the new floor, and (c) punching shear action.

In that cases, where only the replacement of timber beam floors was carried out (i.e., with no other reinforcement works), the consequences were serious. During earthquakes, cracks opened and collapses typically occurred. This problem is far from being solved, as it exists in thousands of buildings where this intervention was applied, highly increasing their seismic vulnerability.

In that period, another typical retrofitting method was RC jacketing of the pre-existing walls. This technique, widely used after the 1976 Friuli quake, was clearly effective in increasing the lateral capacity of the walls, but it was invasive and nonreversible.

To show how limited the knowledge of the mechanics of historic constructions was at the time, we could cite the case of RC ring beams: These were typically inserted in the masonry near the horizontal floors, producing dangerous stress redistribution among the wall leaves and facilitating the out-of-plane collapse of the external walls. Figure 4 shows the collapse mechanism of two retrofitted buildings where RC ring beams were added in the 1980s: The increase of the magnitude of the inertial seismic forces (due to the increase of the mass for the application of the RC ring beam) had a destructive effect on low-quality masonry walls. 

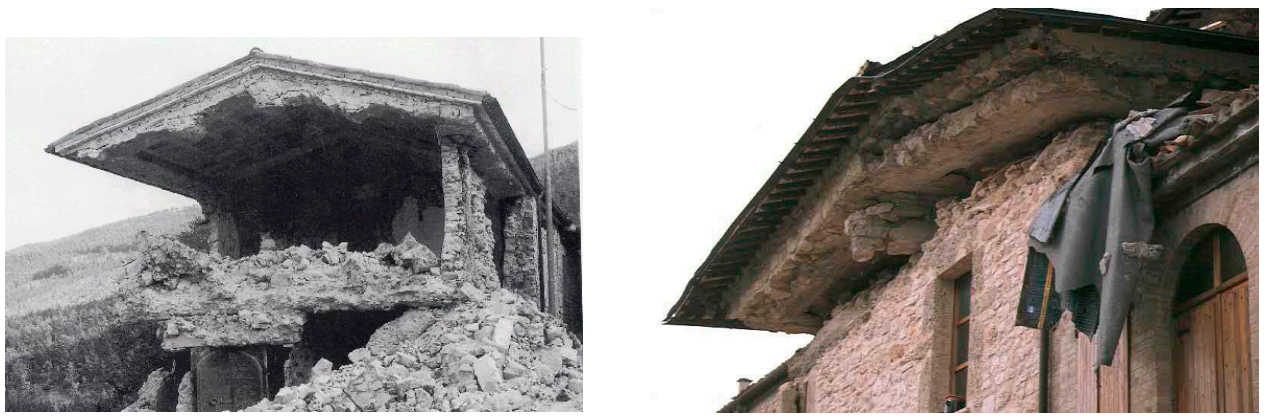

Figure 4. Examples of buildings where replacement of timber beam floor/roof was made (Umbria-Marche 1997 quake).

In Figure 5, the destructive effect of the 2009 L'Aquila earthquake on the parish church of Tempera can be noted: This building was retrofitted in the 1980s with grout injections by the demolition of the pre-existing timber floor, replaced with a new concrete-rib and hollow-block one.

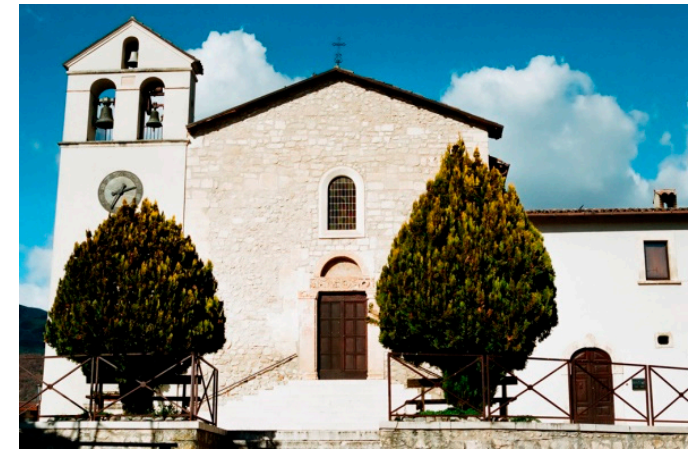

(a)

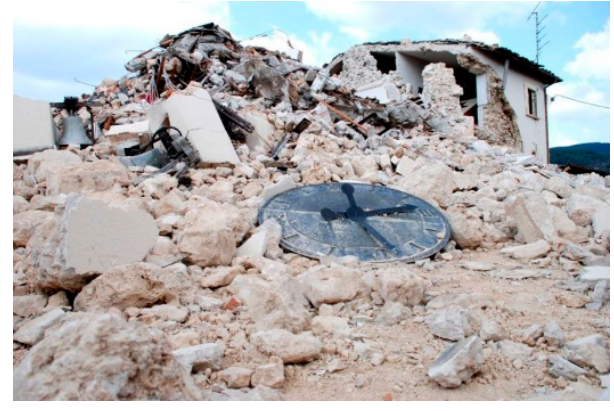

(b)

Figure 5. Parish Church of Tempera, near L'Aquila, before (a) and after (b) the 2009 quake: Replacement of timber-beam roof and grout injections were used to reinforce this historic construction in 1984.

We could classify these problems as "damages induced by Code application", because these problems were the direct consequence of the use of the codes and standards in force at that time. In many situations, both at national and local levels, technicians had to follow operational protocols, not only for interventions on standard historic constructions, but also for works on listed buildings.

The large number of fatalities (3500 in total for the 1976 and 1980 quakes) and the government will to quickly reduce the vulnerability of historic constructions facilitated the introduction of these incorrect retrofitting techniques on large scale. Until 1986, retrofitting interventions were classified in two only categories: "Earthquake-resistant upgrading" (adeguamento sismico in Italian) and "small localized interventions". If the intervention was not "small localized", the only option was to carry out a general earthquake-resistant upgrade, without intermediate possibilities. This facilitated large, invasive, generalized, nonreversible works. In the 1986 Building Code, the intermediate category of an "intervention improving the building's structural response" (miglioramento sismico in Italian) was added.

Limited effectiveness sometimes resulted in grout injections. Non-injectable masonry is common in some areas in Italy, and more attention should be given when using this technique (Figure 5). Injection of grouts, which represents one of the most frequent uses in present building practice, must be preceded by an evaluation of the effective possibility for the injected hydraulic grout to be distributed inside the masonry in an adequate way. Therefore, the choice of the grout, according to the typology of the wall, assumes particular importance, since it can determine whether or not the reinforcing is effective. 
The building Codes in force in that period were the 1977 Friuli Regional Law [29] and 1981 Ministerial Order [30]. These official documents "suggested the use" of the following retrofitting interventions: 1. Grout injections; 2. RC jacketing; 3. insertion of RC frames/pillars into the masonry structure of the buildings; 4 . application of vertical and horizontal steel ties; 5 . demolition of damaged and not well-made curved masonry structures (arches, vaults); 6. extrados-applied new RC thin plates, for vault and arch reinforcement; 7. demolition of deformed timber-beam or damaged floors and replacement with new RC or hollow-core concrete or steel ones; 8. fixed-end beam-steps, inserted in the masonry walls, to be replaced with RC or steel staircases.

Similar interventions were typically applied to listed constructions with limited attention to the cultural value of the buildings. However, it is evident that different attitudes and sensibilities were used at that time, and these methods were commonly accepted by the scientific community and general public. Even before 1980s, interventions consisting of the insertion of RC frames/pillars/beams into the masonry structure of old churches were frequent. Figure 6 shows an intervention, carried out in the 1980s in Gubbio, Italy: A new RC frame was added inside the historic masonry structure and the pre-existing timber roof was demolished and replaced with a heavy and stiff roof, made of concrete ribs and hollow blocks. However, thanks to the evidence of damage after the recent quakes, the scientific community could start understanding that the combination of RC elements with historic masonry material has some critical problems.

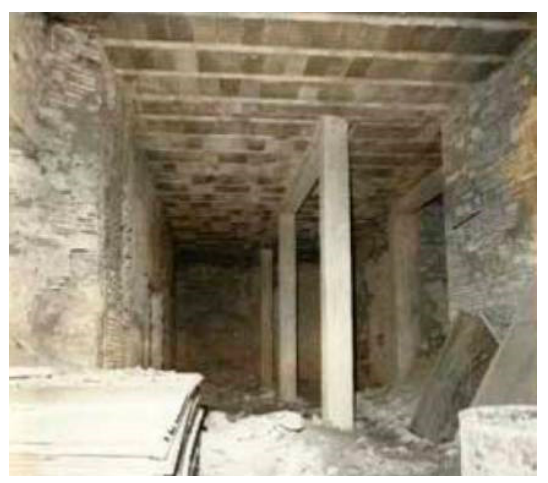

(a)

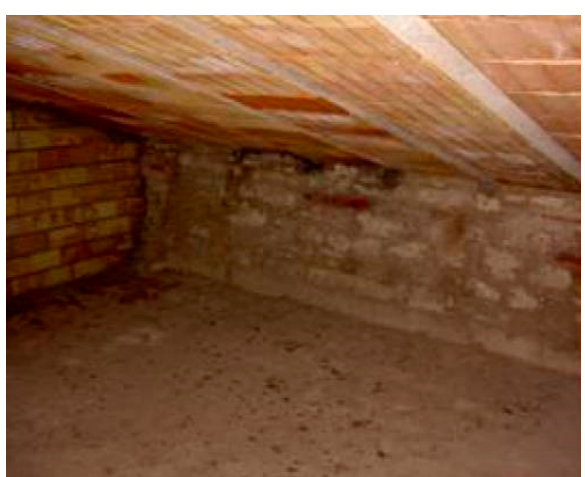

(b)

Figure 6. Example of an intervention carried out on a 14th-century building in Gubbio, Italy in the 1980s: (a) New RC frame, (b) replacement of timber-beam floor with a hollow-core concrete one.

Today, the approach is different and improved attention to the conservation and preservation problems of architectural heritage is widespread and common. However, this attention is subjective and unstable. For example, we should highlight the different methods and solutions used in Italy by local conservation authorities. As an example of this, we could mention the following different interventions used on the vertical elements of these listed constructions: 1 . The flat-jacks inserted in the pillars of the Cathedral of Pavia, Italy (Figure 7a) as a method to induce the migration of the vertical stresses to the inner rubbl-masonry core: The masonry pillars were cut and 1087 flat jacks were used to reduce the compressive stresses in the marble cracked skin of the masonry pillars; 2 . the complete demolition and subsequent reconstruction (using the same stones) of the masonry pillars of Noto Cathedral (Figure $7 \mathrm{~b}$ ); and 3. the use of glass nonstructural elements for the missing columns for Cathedral of Pozzuoli, Italy (Figure 7c). These solutions clearly demonstrate that, in some cases, it is the structural aspect that governs the design process (Figure 7a,b), while the aesthetical one is predominant for other interventions (Figure 7c). 


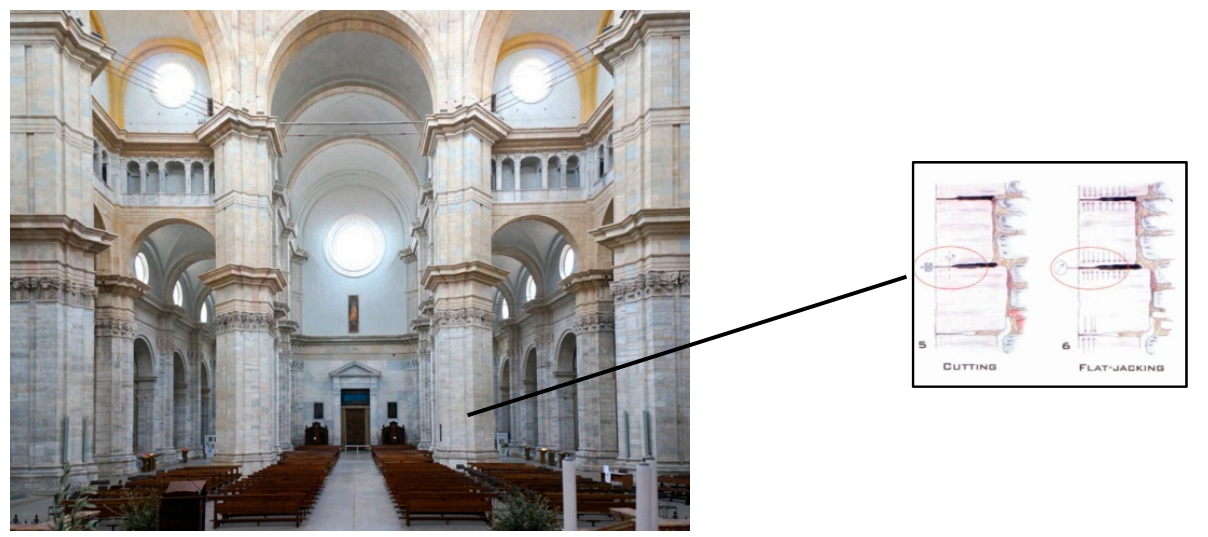

(a)

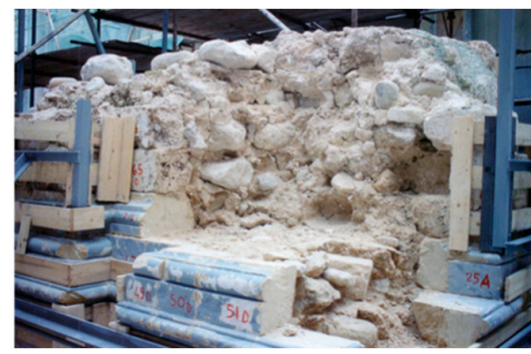

(b)

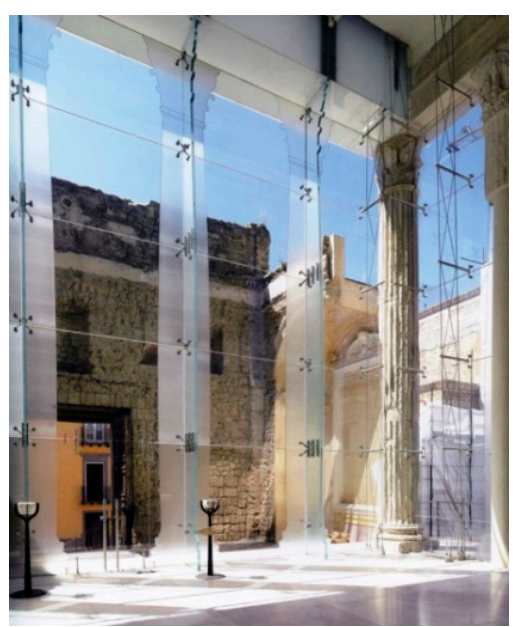

(c)

Figure 7. (a) Intervention with flat-jacks at Cathedral of Pavia: Flat jacks were used on the masonry pillars to facilitate to stress transfer from the cracked marble skin of the pillars to the inner rubble-masonry core; (b) complete demolition and reconstruction (using the stones resulting from previous demolition) of the pillars of the 18th century Noto Cathedral; (c) the use of glass nonstructural elements for the missing columns for the Cathedral of Pozzuoli.

\section{Actual Italian Building Codes and Guidelines}

The reference Code for interventions on architectural heritage in Italy [16] is not the same as the one used by technicians for standard constructions [19]. This is clearly justified by considering the specific characteristics of heritage structures. The aim is to preserve the building without substantially changing it with invasive retrofitting interventions (the well-known principle of "minimum intervention" (minimal (least) intervention (or conservative repair)), as defined in the Venice Charter [31].

The 1939 Act (No. 1039) [32] separated architectural heritage from the remaining building stock: " ... fixed and movable items (i.e. buildings, assets, etc.) with architectural, historic or archeological value ... cannot be demolished, moved, modified or restored without the authorization of the Italian Ministry for Education. These items cannot be used with an intended purpose, that it is not compatible with their historic or artistic character or harmful for their conservation or overall integrity".

The 1986 guidelines [33], issued by the Italian Ministry for Cultural Heritage (Ministero dei Beni Culturali in Italian), clearly specified the principles for the seismic protection of architectural heritage buildings and assets. These principles, with one important exception, constitute the base of recent codes. These guideless highlighted critical aspects: The importance of "a multi-disciplinary approach", "lack of code clarity with reference to the design of interventions, worsened by the habit of using improper building codes in force for standard constructions and not for monuments", "conflict between conservation issues and need for the building's seismic protection (including its users), and related 
acceptance of responsibility", "missing of calibrated and reliable calculation and design procedures". These critical aspects are still a matter of discussion, after 30 years. However, the conclusion reported in the 1986 guidelines ("interventions on the architectural heritage must improve the seismic safety without strictly adhere to the rules and safety requirements for standard new buildings") was very different compared to the actual one.

The 2008 Italian Building codes [19] and the 2011 guidelines [16] draw a distinction between ordinary buildings and listed ones, but unlike in the 1986 guidelines, a numerical assessment of the structural safety is required. The 2008 Building code specifies: "For architectural heritage buildings in areas of seismic risk ...... it is possible to carry out interventions only aimed at improving the building's structural response (miglioramento in Italian) with a preliminary assessment of the safety". This requirement is fully explained in the 2011 Guidelines, in which numerical modeling using finite element analysis or similar methods, unavailable in 1986, is encouraged: "it is clear that it is not always possible to use numerical modeling and design procedures, typically in use for ordinary buildings, to listed monuments. However, it is required to calculate the magnitude of the seismic action corresponding to each limit state of the building, before and after the intervention. To this end, the most reliable numerical methods should be used".

It is known that scientific knowledge in the field of analysis of historic masonry structures is significantly greater compared to 1980s, but a clearer distinction should be drawn between cases where the numerical models are able to capture the structural behavior of the building under investigation, and those cases where nonquantifiable difficulties and errors could affect the analysis.

The solution proposed by the 2011 guidelines [16] is given by the following: "When the contribution of particular constructional characteristics cannot be evaluated in the analysis, the designer can use an adequately justified subjective analysis". This is likely the main fault of the code framework: In the event of nonquantifiable (frequent) difficulties, it is required to evaluate the building safety using numerical methods. These methods are often inappropriate, as it impossible to quantify the unquantifiable.

Furthermore, the importance of the cited multidisciplinary approach of the design process is in contrast with the actual authorization process. An appropriate strategy aimed at protecting the cultural heritage and at reducing the seismic risk should include both conservation and safety issues. These issues should be based not only on comprehensive knowledge of the multifaceted aspects of heritage, but also of the structural methods, actually in use, for retrofit and repair of heritage buildings, especially when located in seismic-prone areas. In this context, the multidisciplinary approach is critical: This should be used in all phases of the intervention-not only during the design, but also during the authorization process and the implementation of the works. This approach requires in-depth knowledge and intimate experience of the related problems for all the people involved (engineers, architects, public officials in the heritage bodies and local governments). These people should be able to use the multidisciplinary method during all phases of the intervention (design, authorization, and implementation phases), according to their role and responsibility. Unfortunately, we note that the competences of engineers are often missing in the statutory conservation bodies in charge of the authorization of the interventions.

\section{Minimum Intervention}

The principle of "Minimum Intervention" is often used when interventions on architectural heritage structures are decided. However, some misunderstandings should be removed from the table. The Italian Code for interventions on these buildings [34] is clear:

"The conservation of architectural heritage buildings is made by means of a coherent, coordinated and scheduled activity of study, prevention, maintenance and restoration. Prevention is defined as the totality of the activities needed to limit risk situations for the heritage constructions. The state, the regions and the other public local and national statutory bodies must ensure the safety and the conservation of the cultural heritage assents in their portfolio". 
It is evident that compliance with the law requires the implementation of appropriate preventive interventions: Manifest responsibilities and accountabilities could arise for unrealized interventions.

The Venice Charter [31] and the subsequent technical notes of ICOMOS state that: "Each intervention should be in proportion to the safety objectives set, thus keeping intervention to the minimum to guarantee safety and durability with the least harm to heritage values" [35]. Although this is clearly defined, the principle of "Minimum Intervention" is often misinterpreted. Minimum intervention does not mean "no intervention" or "next to nothing". From an appropriate analysis of the aforementioned point of the ICOMOS technical note, it can be concluded: 1. "Safety" is a critical aspect to consider, and 2. the intervention should be decided based on its characteristics in terms of safety and durability with the least harm to heritage values.

This means that, if the heritage building under consideration is located in an area at high seismic hazard (likely to be struck by a seismic event in the medium or long run), for example, the Nera's Valley in Umbria, Italy, according to the principles of ICOMOS, minimum intervention can be identified between the ones able to guarantee that the building will not collapse. When choosing which possible solution to implement, the one with the least harm to heritage values will be adopted.

It is worth noting that to find this "meeting point" between safety and conservation, it is essential to have appropriate knowledge of both these aspects for the heritage building under consideration. This knowledge should be the highest possible (otherwise, it cannot be stated that the chosen intervention is "needed" for the safety and "least" for the harm).

Based on this, if these interventions are omitted or not allowed, this will lead to costs not only in terms of loss of heritage values, produced by the ruin of the buildings, but also for their subsequent reconstruction.

This can be demonstrated by considering what has been spent for the reconstruction of architectural heritage buildings (mainly religious masonry structures) in Umbria and Emilia, after the 1997 and 2012 quakes, respectively. In many situations, the adopted solution was "exactly as it was". The 2016 Central Italy earthquake completely destroyed many buildings, only a few years after their restoration or reconstruction. However, it is true that interventions on religious buildings for their special features and characteristics are more difficult and complex, but something should be done to prevent this situation from arising again.

\section{Excess of Delegation, Ignorance, and Inaction}

It is worth citing what has happened in Abruzzo in the 1960s and 1970s. An excess of delegation to structural engineers caused the implementation of inappropriate and incorrect retrofitting interventions on listed stone masonry buildings. The application of heavy RC ring beams and the replacement of timber beam floors with RC ones was frequently carried out, and this produced significant damage to historic buildings during earthquakes. Figure 8 shows the effect of the 2009 L'Aquila earthquake on the masonry building of St. Mary of Paganica church: The roof, after the demolition of the timber structure in the 1970s, was made of a heavy RC slab, hollow blocks, and RC ribs.

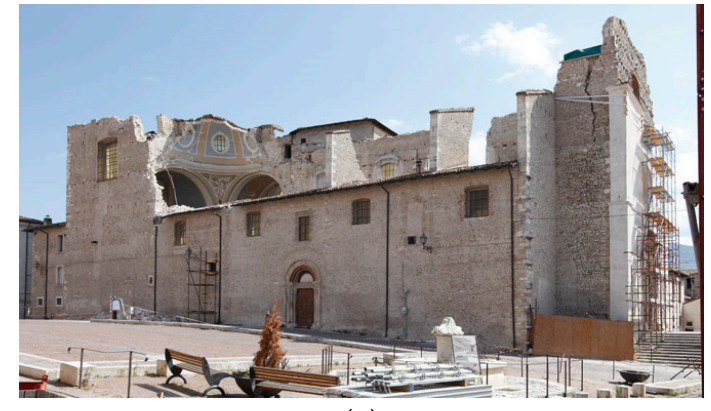

(a)

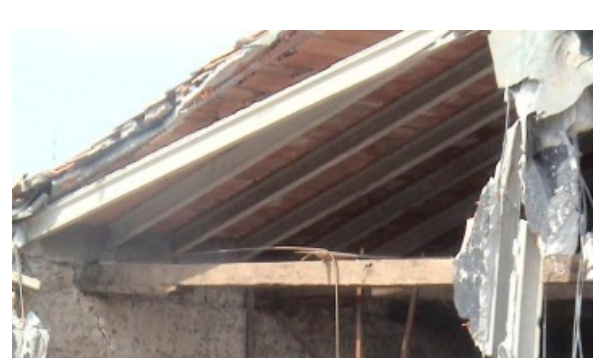

(b)

Figure 8. (a) St. Mary of Paganica (S. Maria di Paganica in Italian) in L'Aquila after the 2009Abruzzo earthquake; (b) detail of the roof structure. 
Another issue is the "damage produced by inaction". This is the case of buildings in need of structural retrofitting intentions, where these works were not implemented. The reasons for this can be many: Bureaucratic inefficiencies, funding issues, preferred options for non-intervention, or inertia.

Finally, we could also mention here the "damage produced by the lack of knowledge of the structural issues". This is more frequent and common than anyone can image. The causes of this are many: Missing structural engineering skills, aesthetic requirements, recognizability of interventions (according to the "invisible from a distance, identifiable from close up"). An example of this is the required misalignment of two façade walls in a terrace building when one wall is new and the other is historic. This facilitated their recognizability but increased the seismic vulnerability of the construction. Figure 9a shows a historic terrace building in Italy after the 2009 L'Aquila earthquake: Aligned terrace buildings can exhibit a satisfactory seismic behavior when in-plane loaded, due to mutual wall confinement. Opposite, misalignment of the facades (Figure 9b) can highly increase the risk for serious damage during an earthquake.

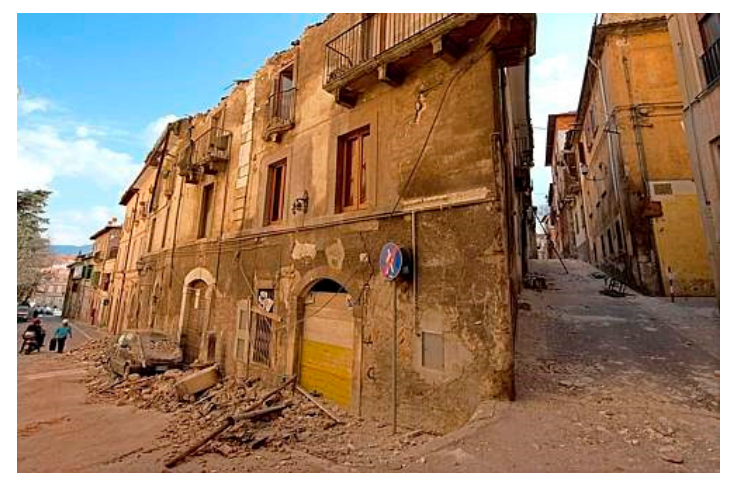

(a)

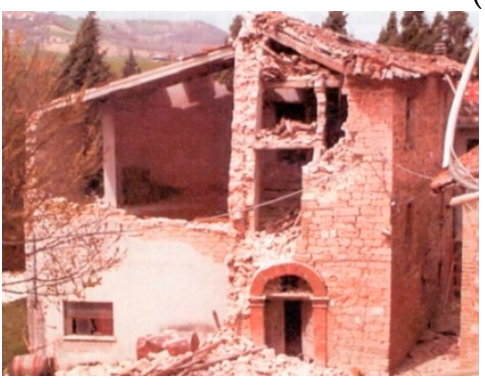

(b)

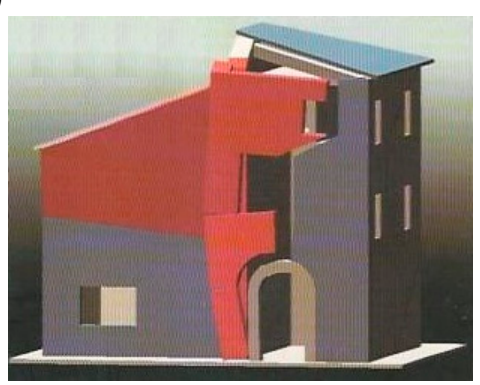

(c)

Figure 9. (a) Aligned terrace buildings can exhibit a satisfactory seismic behavior when in-plane loaded, due to mutual wall confinement. However, misalignments of the façade walls are common in historic construction. The effect of misalignment of two façade walls when one wall is new and the other is historic: (b) The building after the quake, (c) the masonry macroelements and their mechanism (Umbria 1997 earthquake).

Leaving a small part of a stone work wall unreinforced is another example of recognizability. Figure 10 shows a historic stone building where RC jacketing was applied to reinforce the walls. However, a portion of the masonry was left unreinforced and visible (fair-faced aspect) to facilitate recognizability: This highly increased the seismic vulnerability of the building, facilitating its collapse during the 2009 L'Aquila earthquake. 


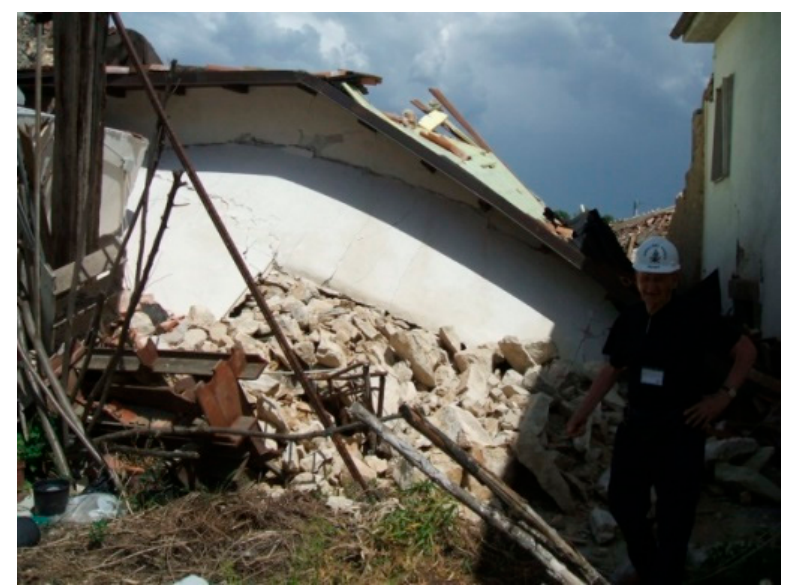

Figure 10. Example of ruined historic building with a portion of the façade wall left unreinforced (fair-faced aspect), without the application of RC jacketing.

Finally, the removal of seismic interventions and reinforcements, although applied in the past, is another error not difficult to detect in historic constructions. Figure 11a shows the bolted endplates of the steel ties applied in the 19th century on the masonry vaults of the Fortezza Spagnola in L'Aquila. A thorough inspection of the vaults from inside, using the available photographic evidence before and after the 2009 quake (Figure 11b), demonstrates that steel ties had been removed. The consequence of this was a serious damage of the untied vaults during the 2009 earthquake (hinge-mechanism in the vaults and overturning of the side walls).

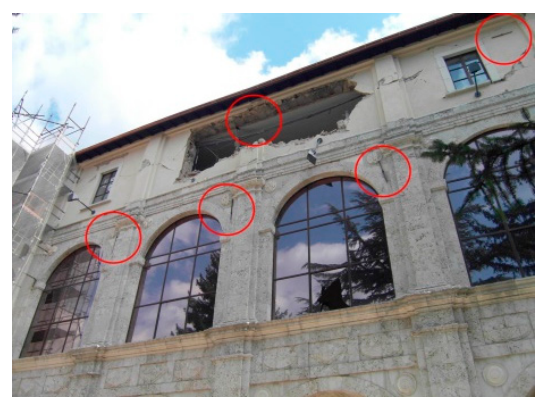

(a)

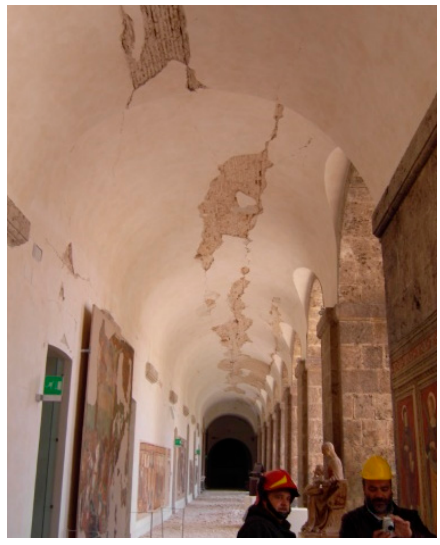

(b)

Figure 11. Fortezza Spagnola, L'Aquila, Italy: (a) The bolted endplates of the steel ties are clearly visible on the façade of the building. (b) However, the steel ties are missing inside the corresponding vaulted zone. These were likely removed in a previous restoration.

\section{Lessons from 2016 Central Italy Earthquake}

Many URM heritage buildings are located in Central Italy. Of these, many are protected by Conservation bodies or local governments, or if not actually protected, nevertheless an important part of Italian architectural heritage. This part of the country was struck by a destructive earthquake in 2016. The quake produced significant damage to the architectural heritage. It is striking that limited or ineffective protection was given by the statutory conservation bodies to these monuments. No preventive intervention, aimed at increasing the structural response of the listed historic buildings located in this area, was carried out in the past. In detail, churches and religious buildings in general, although the seismic vulnerability of these monuments was often evident and demonstrated by 
previous scientific studies [36,37], suffered great damage from the 2016 earthquake and, in some cases, were completely destroyed.

We analyzed several churches located near Norcia, Italy and, in most cases, we noted a macroscopic underestimation of the structural problems [38,39]. Figures 12-14 show different religious buildings, before and after the 2016 Central Italy quake. These churches often underwent restoration works in the last 10-30 years, but little was done to improve their structural behavior. Some of these problems could be solved using simple, cost-effective, and non-invasive retrofitting measures. Nevertheless, it is difficult to state with any certainty that the churches could have been preserved if these interventions had been carried out. However, with these structural interventions, their seismic vulnerability would have surely decreased.

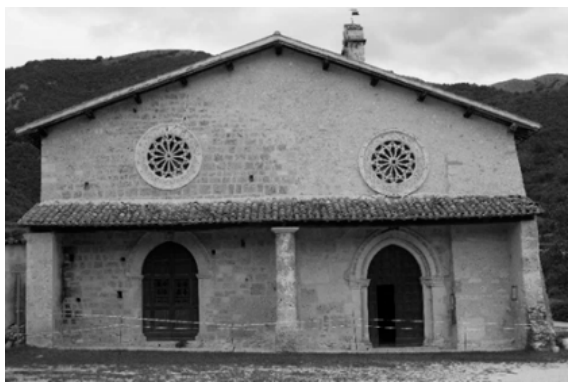

(a)

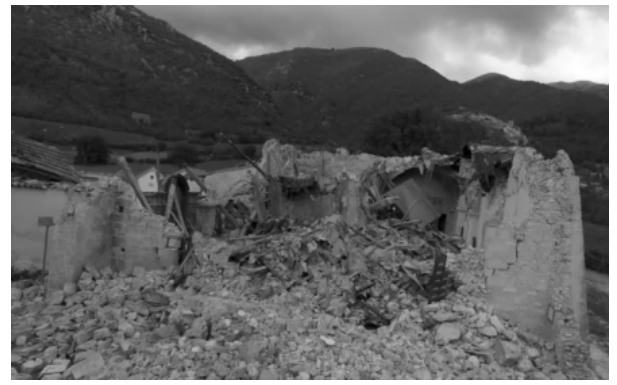

(b)

Figure 12. St. Savior's, near Norcia, Italy: Before (a) and after (b) the quake.

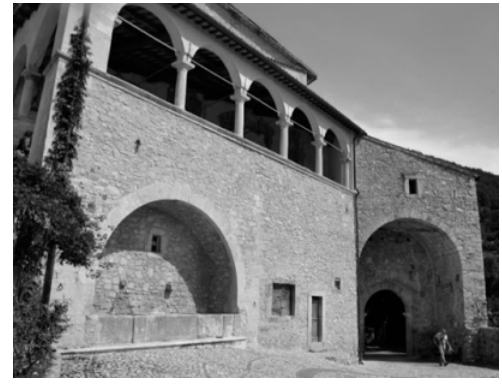

(a)

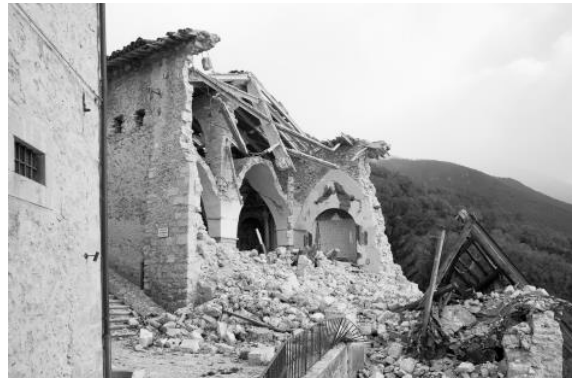

(b)

Figure 13. St. Andrew's in Campi, Norcia, Italy: Before (a) and after the quake (b).

In the past, local conservation bodies and other heritage institutions used a very large amount of State aid for the restoration of frescos and other assets inside these churches. We would like to remind here that conservation also (and, let us say, primarily) means protecting the historic masonry structures from destruction, especially if these are located in areas of high seismic hazard. In summary, we believe that more effort has to be given to the application of well-known seismic-protection devices like steel ties, and only after structural interventions are completed should restoration of the internal heritage assets be implemented. In fact, the overturning (out-of-plane mechanism) of the lateral walls can be often prevented by applying steel ties. This intervention has significant positive characteristics in terms of cost-effectiveness, lightness, reversibility, and compatibility with historic masonry material. Unfortunately, we note that the restoration method described above, focused only on the interventions of the nonstructural heritage assets, has been diffusively used everywhere in Italy. It is sad to say that the next seismic event will again produce irreversible damage and loss to architectural and cultural heritage. 


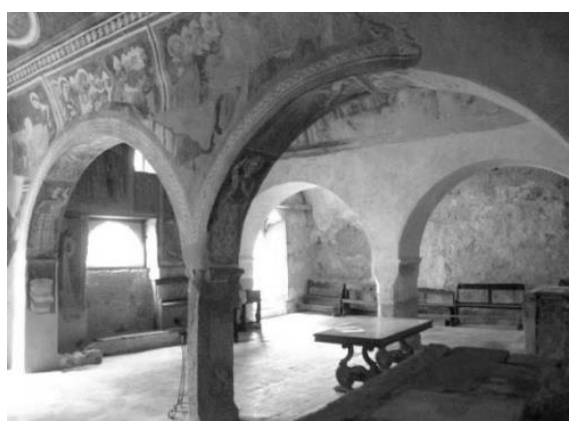

(a)

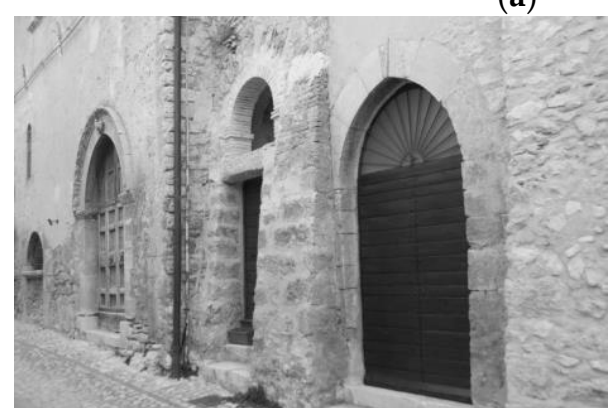

(b)

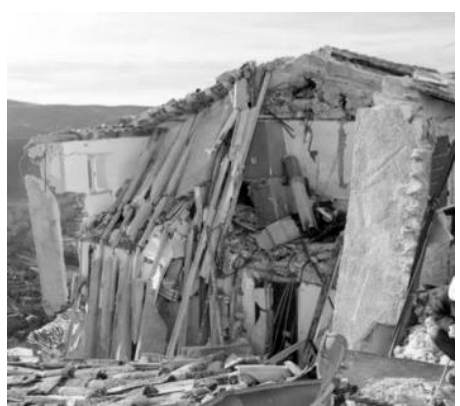

(c)

Figure 14. St. Mary's in Campi, Norcia, Italy: Before (a,b) and after the quake (c).

\section{Conclusions}

Historic masonry buildings are in Italy an important part of the national heritage. While they have survived, sometimes for hundreds of years, they will not survive indefinitely without periodic care and attention. In this paper, a discussion about the importance of the structural safety for monuments located in territories of high seismic hazard was presented. It was demonstrated that we can learn from past mistakes and prepare for a new approach and more effective activities. Some past errors have been reported and discussed in this paper: These ranged from exaggerated structurally-oriented interventions to nonstructural interventions of buildings located in areas at high seismic risk. Incorrect retrofitting methods, excess of delegation, ignorance and inaction, and misinterpretation of seismic codes were used in the past in Italy for interventions on masonry buildings belonging to the architectural heritage.

One of the most serious mistakes that has been made was not bridging the cultural divide between structural engineers, conservators, art historians, archeologists, and architects. To reduce the effects of this, structural engineers and conservators must set up an improved dialogue. This could be based on special opportunities to meet and debate. In this context, compulsory professional development training could be used to inform about the concepts of a "conscious reinforcement" and "conscious restoration". Structural engineers should apply a conscious reinforcement when they design structural interventions. This is based on the knowledge of the basic conservation notions. In a similar way, conservators should make use of a conscious restoration in their nonstructural interventions. A conscious restoration is based on the basic knowledge of the notions of structural mechanics. We also believe that the expertise of structural engineers should be available within the conservation statutory organizations.

The issue of responsibilities is another important aspect to consider. Responsibilities are actually punitive for engineers in charge of the intervention's design and technicians in charge of the functional verification (this latter is typically needed after a seismic event to check the structural state of the buildings). The Italian Guidelines [15] clearly state: "For cultural heritage buildings it is often advisable to accept a higher seismic risk compared to ordinary buildings, rather than make interventions in disagreement with the conservation notions". By accepting this, it is clear that the responsibility for 
non-interventions or partial retrofitting, causing damages or collapses during future earthquakes, lies entirely with the technicians and engineers.

After a seismic event or at the end of a retrofitting/repair intervention, the procedure to follow, according to the Italian Building Code, requires the engineer or the technician (for all buildings, also including the listed ones) to authorize their use, giving them strict liability. In fact, the structural engineer has to complete a written consent certificate. Ultimately, they have to assume the risk of the conservation of the buildings under consideration, and this means conscientiously accepting the main responsibility for future failures or damages.

Author Contributions: Conceptualization, A.B.; methodology, M.C.; formal analysis, A.B.; writing—original draft preparation, M.C.; writing — review and editing, M.C. and A.B.

Funding: This research was funded by the Italian Government through the project "ReLUIS 2017-Linea murature" and ReLUIS SISMA 2016.

Acknowledgments: This work has been supported by the ReLuis project. The authors are also grateful to the Italian Ministry of Cultural Heritage and Activities and Tourism (MiBACT).

Conflicts of Interest: The authors declare no conflict of interest.

\section{References and Notes}

1. Giuffrè, A. Letture Sulla Meccanica Delle Murature Storiche; Kappa: Rome, Italy, 1999. (In Italian)

2. Rovero, L.; Alecci, V.; Mechelli, J.; Tonietti, U.; De Stefano, M. Masonry walls with irregular texture of L'Aquila (Italy) seismic area: Validation of a method for the evaluation of masonry quality. Mater. Struct. 2016, 49, 2297-2314. [CrossRef]

3. Corradi, M.; Borri, A. A database of the structural behavior of masonry in shear. Bull. Earthq. Eng. 2018, 16, 3905-3930. [CrossRef]

4. Karantoni, F.; Bouckovalas, G. Description and analysis of building damage due to Pyrgos, Greece earthquake. Soil Dyn. Earthq. Eng. 1997, 16, 141-150. [CrossRef]

5. Corradi, M.; Borri, A.; Vignoli, A. Experimental study on the determination of strength of masonry walls. Constr. Build. Mater. 2003, 17, 325-337. [CrossRef]

6. Lagomarsino, S.; Podestà, S. Damage and vulnerability assessment of churches after the 2002 Molise, Italy, earthquake. Earthq. Spectra 2004, 20, 271-283. [CrossRef]

7. Binda, L.; Saisi, A. Research on historic structures in seismic areas in Italy. Prog. Struct. Eng. Mater. 2005, 7, 71-85. [CrossRef]

8. Cardoso, R.; Lopes, M.; Bento, R. Seismic evaluation of old masonry buildings. Part I: Method description and application to a case study. Eng. Struct. 2005, 27, 2024-2035. [CrossRef]

9. D'Ayala, D.F.; Paganoni, S. Assessment and analysis of damage in L'Aquila historic city centre after 6th April 2009. Bull. Earthq. Eng. 2009, 9, 81-104. [CrossRef]

10. Sorrentino, L.; Liberatore, L.; Decanini, L.D.; Liberatore, D. The performance of churches in the 2012 Emilia earthquakes. Bull. Earthq. Eng. 2014, 12, 2299-2331. [CrossRef]

11. Forster, A.M. Building conservation philosophy for masonry repair: Part 2-“Principles". Struct. Surv. 2010, 28, 165-188. [CrossRef]

12. Maniatakis, C.A.; Spyrakos, C.C.; Kiriakopoulos, P.D.; Tsellos, K.P. Seismic response of a historic church considering pounding phenomena. Bull. Earthq. Eng. 2018, 16, 2913-2941. [CrossRef]

13. Italian National Geophysics and Volcanology Center [Istituto Nazionale di Geofisica e Vulcanologia]. First Summary Report on the 26 October 2016, Visso Earthquake in Central Italy; Italian National Geophysics and Volcanology Center: Catania, Italy, 2016.

14. Italian National Geophysics and Volcanology Center [Istituto Nazionale di Geofisica e Vulcanologia]. First Summary Report on the 24 August 2016, Amatrice Earthquake in Central Italy; Italian National Geophysics and Volcanology Center: Catania, Italy, 2016.

15. Italian National Geophysics and Volcanology Center [Istituto Nazionale di Geofisica e Vulcanologia]. First Summary Report on the 30 October 2016, Central Italy Earthquake; Italian National Geophysics and Volcanology Center: Catania, Italy, 2016. 
16. Italian Building Code. Guidelines: Assessment and Mitigation of Seismic Risk of Cultural Heritage with Reference to the 2008 Italian Building Code [Linee Guida per la Valutazione del Rischio Sismico del Patrimonio Culturale Allineate alle Nuove norme Tecniche per le Costruzioni]; G.U. No. 47; 2011. (In Italian)

17. Cannistraro, G.; Cannistraro, M.; Restivo, R. Messina's historical buildings after the earthquake of 1908: Energy and environmental analysis through a global screening methodology. Int. J. Heat Technol. 2013, 31, 155. [CrossRef]

18. Cannistraro, G.; Cannistraro, M.; Piccolo, A.; Restivo, R. Potentials and limits of oxidative photocatalysisand: Possible applications in the Field of Cultural Heritage. Adv. Mater. Res. 2013, 787, 111-117. [CrossRef]

19. Italian Building Code [Nuove Norme Tecniche per le Costruzioni]; G.U. No. 29; 2008. (In Italian)

20. Italian Building Code, General Instructions to the Italian Building Code; G.U. No. 617; 2009. (In Italian)

21. Pickard, R. Policy and Law in Heritage Conservation; Tylor \& Francis: London, UK, 2001.

22. Ahmad, Y. The scope and definitions of heritage: From tangible to intangible. Int. J. Herit. Stud. 2006, 12, 292-300. [CrossRef]

23. Giuffrè, A. Sicurezza e Conservazione dei Centri Storici. Il Caso Ortigia; Laterza: Bari, Italy, 1993. (In Italian)

24. Borri, A.; Corradi, M.; Castori, G.; De Maria, A. A method for the analysis and classification of historic masonry. Bull. Earthq. Eng. 2015, 13, 1-19. [CrossRef]

25. Dizhur, D.; Ingham, J.; Moon, L.; Griffith, M.; Schultz, A.; Senaldi, I.; Magenes, G.; Dickie, J.; Lissel, S.; Centeno, J.; et al. Performance of ma-sonry buildings and churches in the 22 February 2011 Christchurch earthquake. Bull. N. Z. Soc. Earthq. Eng. 2011, 44, 279-296.

26. Lourenço, P.B.; Trujillo, A.; Mendes, N.; Ramos, L.F. Seismic performance of the St. George of the Latins church: Lessons learned from studying masonry ruins. Eng. Struct. 2012, 40, 501-518. [CrossRef]

27. Borri, A.; Corradi, M. Structural engineers vs. conservators, safety vs. preservation: Problems, doubts and proposals. In Proceedings of the 1st International Conference (TMM_CH) Transdisciplinary Multispectral Modelling and Cooperation for the Preservation of Cultural Heritage, Athens, Greece, 10-13 October 2018.

28. Tomaževic, M. The Computer Program POR, Report ZRMK. 1978. (In Slovenian)

29. Friuli Venezia Giulia Regional Act. Intervention Methods and Procedures on Pre-Existing Buildings [Documentazione Tecnica per la Progettazione e Direzione delle Opere di Riparazione Degli Edifici]; No. 30; 1977. (In Italian)

30. Italian Building Code, Repair and Retrofit Methods of Damaged Buildings in Basilicata, Campania and Puglia [Normativa per le Riparazioni ed il Rafforzamento Degli Edifici Danneggiati dal Sisma Nelle Regioni Basilicata, Campania e Puglia]; G.U. No. 198; 1981. (In Italian)

31. ICOMOS Charter, International Charter for the Conservation and Restoration of Monuments and Sites, Venice, Italy, 1964.

32. Italian Act, Protection of Cultural and Historic Heritage [Tutela delle Cose D'interesse Artistico e Storico]; No. 1089; 1939. (In Italian)

33. Italian Building Code, Guidelines: Recommendations for Interventions on Cultural Heritage Monuments in Seismic Prone Areas [Interventi sul Patrimonio Monumentale a Tipologia Specialistica in Zone Sismiche: Raccomandazioni], No. 1032; 1986. (In Italian)

34. Italian Act, 22 January 2004, No. 42 "Codice dei beni culturali e del Paesaggio, ai sensi dell'articolo 10 della Legge 6 luglio 2002, n.137"; 2004. (In Italian)

35. ICOMOS Charter, Principles for the Analysis Conservation and Structural Restoration of Architectural Heritage; 2003.

36. Binda, L.; Cardani, G.; Modena, C.; Valluzzi, M.R.; Marchetti, L. Indagine sulla consistenza dell'edilizia storica, sul danno pregresso e sull'efficacia degli interventi svolta su quattro centri campione in Umbria. In Proceedings of the 9th National Conference on Seismic Engineering in Italy ANIDIS, Genova, Italy, 25-29 January 2004.

37. Cardani, G. La Vulnerabilità Sismica dei Centri Storici: Il caso di Campi Alto di Norcia. Linee Guida per la Diagnosi Finalizzata alla Scelta delle Tecniche di Intervento per la Prevenzione dei Danni. Ph.D. Thesis, Technical University of Milan, Milan, Italy, 2003. (In Italian) 
38. Borri, A.; Corradi, M.; Castori, G.; Sisti, R.; De Maria, A. Analysis of the collapse mechanisms of medieval churches struck by the 2016 Umbrian earthquake. Int. J. Archit. Herit. 2018. [CrossRef]

39. Sisti, R.; Di Ludovico, M.; Borri, A.; Prota, A. Damage assessment and the effectiveness of prevention: The response of ordinary unreinforced masonry building in Norcia during the Central Italy 2016-2017 seismic sequence. Bull. Earthq. Eng. 2018. [CrossRef] 